\title{
Corticosteroid-responsive Epilepsia Partialis Continua
}

\author{
Kortikosteroide Yanttl Epilepsiya Parsiyalis Kontinua
}

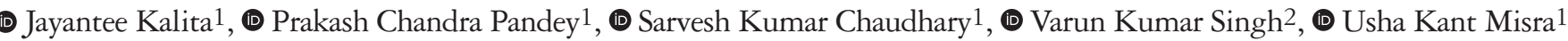

1Sanjay Gandhi Postgraduate Institute of Medical Sciences, Department of Neurology, Uttar Pradesh, India

2Institute of Medical Sciences, Banaras Hindu University, Department of Neurology, Uttar Pradesh, India

\begin{abstract}
Epilepsia partialis continua (EPC) is a rare form of status epilepticus and often refractory to antiepileptic drugs (AEDs). Persistent seizure activity may increase pro-inflammatory biomarkers locally, which may respond to adjunctive corticosteroid treatment, especially in central nervous system (CNS) infections. We report four children with refractory EPC and the effect of adjunctive corticosteroid in controlling EPC. The duration of EPC ranged between 3 days and 7 months. One patient had secondary generalized convulsive status epilepticus. Cranial computed tomography/magnetic resonance imaging was abnormal in three out of four patients; revealing old infarction in one, tuberculoma in one, and neurocysticercosis in one. Electroencephalography revealed spike and sharp wave discharges on the corresponding cerebral hemisphere. The EPC was refractory to 2-6 AEDs. Following corticosteroid treatment, EPC remitted in two patients with CNS infection, and those with infarction and cryptogenic EPC converted to discrete seizures. In AED-resistant EPC, a short course of corticosteroid may be helpful.
\end{abstract}

Keywords: Epilepsia partialis continua, refractory epilepsy, corticosteroid, MRI, EEG

$\ddot{O} \mathbf{z}$

Epilepsiya parsiyalis kontinua (EPK) nadir görülen bir status epileptikus şeklidir ve sıklıkla antiepileptik ilaçlara (AEİ) dirençlidir. Sürekli nöbet aktivitesi, proenflamatuvar biyobelirteçleri lokal olarak artırabilir ve özellikle merkezi sinir sistemi (MSS) enfeksiyonlarında adjuvan kortikosteroid tedavisine yanıt verebilir. Bu yazıda refrakter EPK'si olan dört çocuğu ve EPK'yi kontrol etmede adjuvan kortikosteroidin etkisini bildirmek istedik. EPK süresi 3 gün ile 7 ay arasında değişiyordu. Bir hastada sekonder jeneralize konvülsif status epileptikus vardı. Kraniyal bilgisayarlı tomografi/manyetik rezonans görüntüleme dört hastadan üçünde anormaldi; bir hastada eski enfarkt, bir hastada tüberkülom ve diğer hastada nörosistiserkoz ile uyumlu lezyonlar mevcuttu. Elektroensefalografide, lezyon tarafındaki hemisferde diken ve keskin dalga deşarjları görüldü. EPK, 2-6 AEİ'ye dirençliydi. Kortikosteroid tedavisini takiben EPK; MSS enfeksiyonu olan iki hastada geriledi, enfarktı olan hastada ve kriptojenik EPK'li hastada birbirinden ayrı nöbetlere dönüştü. AEİ'ye dirençli EPK'de, kısa bir kortikosteroid kürünün tedavide faydası olabilir.

Anahtar Kelimeler: Epilepsiya parsiyalis kontinua, refrakter epilepsi, kortikosteroid, MRG, EEG

\section{Introduction}

Epilepsia partialis continua (EPC) is a rare form of status epilepticus (SE). It was first described by Kozhevnikov as "a condition of continuously repeated fragments of epileptic seizures (motor or sensory) with preserved consciousness lasting for $>1$ hour representing locally restricted epileptic activity" (1). Usually, EPC is refractory to antiepileptic drug (AED) treatment leading to persistence of EPC for months to years (2). The etiology of EPC is also diverse ranging from infective, immunological, vascular to developmental anomalies. Intravenous immunoglobulin (IVIG) and methylprednisolone have been shown to abort SE in autoimmune encephalitis (3). SE due to central nervous system (CNS) infection may be due to predominant inflammation and antiinflammatory drugs may be helpful. There is a paucity of studies reporting the effect of corticosteroids in EPC $(4,5)$. We report the effect of adjunctive corticosteroid treatment in four children with EPC.

\section{Case Reports}

\section{Patient 1}

An 8-month-old girl was having left hemi-convulsions from the age of one month. It lasted for 15-20 minutes, recurring every 3-5 minutes. She had neonatal hypoxia. There was no family history

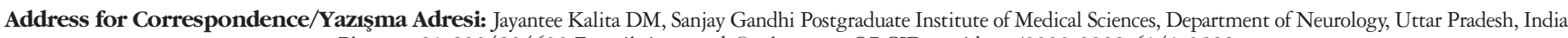
Phone: +91-8004904630 E-mail: jayanteek@yahoo.com ORCID: orcid.org/0000-0002-6141-3592

Received/Geliş Tarihi: 21.07.2020 Accepted/Kabul Tarihi: 05.10.2020

${ }^{\circ}$ Copyright 2021 by Turkish Neurological Society

Turkish Journal of Neurology published by Galenos Publishing House. 
of seizures. Her hemoglobin, blood counts, serum chemistry, and cerebrospinal fluid (CSF) examination were normal including the test for aminoaciduria. A computed tomography (CT) scan of the brain revealed an old infarction in the right anterior cerebral artery territory. Her electroencephalography (EEG) revealed epileptiform discharges mainly on the right side. In addition to her existing AEDs (sodium valproate and levetiracetam), she was prescribed carbamazepine and clobazam. She was prescribed prednisolone 7.5 $\mathrm{mg} /$ day because her seizures were not controlled till the $7^{\text {th }}$ day of hospitalization. After two days, the seizure frequency reduced by $50 \%$ and at one month by $80 \%$. She had 1-2 discrete left focal convulsions lasting for $30 \mathrm{sec}$ to $1 \mathrm{~min} /$ day. After 1 month, the dose of prednisolone gradually tapered in the next month. There was no EPC in the 6 months' follow-up, but she had four discrete seizures.

\section{Patient 2}

A 9-year-old boy presented with a 13-day history of recurrent tonic-clonic movements of the left upper limb and face. On the first day, these attacks lasted for 2-3 minutes and recurred every 10 minutes without loss of consciousness. From the second day, his EPC became continuous and developed left hemiparesis on the fourth day. He was treated with phenytoin sodium, sodium valproate, and clobazam without response. He was admitted to our hospital on day 13. A neurologic examination revealed left face-arm-leg weakness. Muscle tone and tendon reflexes on the left side were reduced but sensations were normal. His blood leucocyte counts, serum chemistry, erythrocyte sedimentation rate, thyroid hormones, chest radiograph, and electrocardiogram were normal. Magnetic resonance imaging (MRI) of the brain revealed enhancing granuloma in the right frontoparietal region with focal meningeal enhancement. EEG revealed background activity of theta range with epileptiform discharges (spike and sharp waves) on the right side. CSF analysis revealed 30 cells (60\% lymphocytes), glucose $63 \mathrm{mg} / \mathrm{dl}$, and protein $64 \mathrm{mg} / \mathrm{dl}$. The CSF smear, culture, and polymerase chain reaction for Mycobacterium tuberculosis, cryptococcal antigen and toxoplasma IgM were negative. He was prescribed four-drug antitubercular therapy. He was prescribed lorazepam $4 \mathrm{mg}$ IV, following which seizures subsided for 30 min only. He also received carbamazepine, levetiracetam, and topiramate sequentially, but seizures continued. On day 20 of EPC, he was treated with IV methylprednisolone $500 \mathrm{mg}$ daily for 5 days. After the third dose, EPC converted to discrete seizures, and after the fifth dose, there was complete remission of seizures. He was prescribed prednisolone $30 \mathrm{mg}$ /day for one month, which was then tapered off in the next month. At one month, he was able to walk independently with mild hemiparesis, and AEDs were reduced to three (carbamazepine, levetiracetam and valproate), and at 4 months AEDs were reduced to two (carbamazepine and levetiracetam). He had no breakthrough seizures at one year follow-up.

\section{Patient 3}

A 17-year-old boy presented with right focal with secondary generalized convulsive SE lasting for 30-35 min, 10-12 such episodes occurring daily for 15 days. He had focal epilepsy 8 years ago and was on remission with carbamazepine and phenobarbitone. There was no apparent cause of breakthrough seizures. At admission, he was conscious, and general physical and neurologic examinations revealed no abnormalities. Blood counts, serum chemistry, electrocardiogram, and contrast cranial MRI were normal. EEG revealed spikes and sharp waves on the left side. During hospitalization, SE was controlled for an hour following IV lorazepam $4 \mathrm{mg}$ but it recurred with occasional generalization. He was prescribed intramuscular dexamethasone $8 \mathrm{mg}, 8$ hourly for 5 days then tapered off in the next 4 days. On the $3^{\text {rd }}$ day, SE converted to 6 discrete focal seizures lasting for 3-4 mins, and on the $8^{\text {th }}$ day, it was reduced to only 2 focal seizures lasting for 30 $60 \mathrm{sec}$. Later, perampanel $4 \mathrm{mg}$ daily was added, and he became seizure-free for the last 6 months.

\section{Patient 4}

An 11-year-old boy had focal epilepsy and encephalopathy four years ago, and his cranial CT scan revealed multiple neurocysticercoses. His seizure was controlled with sodium valproate and clobazam, and was independent for activities of daily living for 4 years. He visited us with a 3 days history of right-sided EPC. He was conscious and did not have focal neurologic deficit. $\mathrm{He}$ was prescribed adjunctive prednisolone $20 \mathrm{mg}$ daily along with ongoing AEDs, and his EPC subsided by day 5 .

The details of all four patients are presented in Table 1, and their EEG and imaging are shown in Figure 1.

\section{Discussion}

The EPC in all four patients responded to corticosteroids; two with ring-enhancing granulomas had complete remission, and the other two with old infarct and normal MRI had partial remission. The contribution of corticosteroid in the remission of EPC was considered because of the temporal relationship of corticosteroid, and reduction in frequency and seizure duration. Moreover, all the

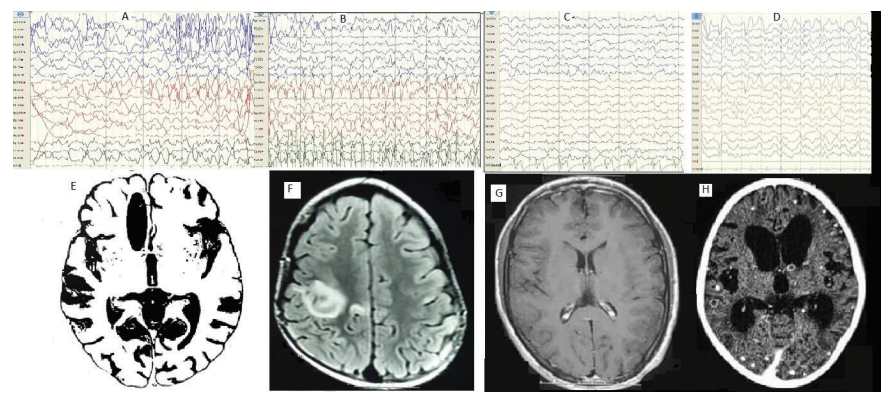

Figure 1. Electroencephalography (EEG) and cranial imaging findings in the children with epilepsia partialis continua: Patient 1: (A) EEG showing spikes, sharp waves and spike and slow waves mainly on the right side, and also in the left frontocentral region. (E) Sketch of cranial CT scan findings in axial section showing old infarction in the right anterior cerebral artery territory (oval black area). Patient 2: (B) EEG showing background theta activity with spikes and sharp waves on the right side. (F). Cranial MRI on FLAIR sequence showing hyperintense ring with central hypointensity which was enhancing on T1 contrast (not shown). Patient 3: (C) EEG shows theta slowing with spikes and sharp waves on the left side. (G) Cranial MRI on T1 contrast sequence shows no abnormality. Patient 4: (D) EEG shows theta to delta slowing with some spikes and sharp waves on the left side. $(\mathrm{H})$ Contrast CT scan shows multiple ring-enhancing lesions, and few cystic lesions with a scolex. There are some calcific lesions as well, confirmed on plain CT

CT: Computed tomography, MRI: Magnetic resonance imaging 
patients had refractory EPC and were unresponsive to multiple AEDs before corticosteroid treatment. In the first two patients, multiple AEDs were tried for 7 days before the corticosteroid treatment. In the latter two patients, we added corticosteroid without escalating the AEDs. Treatment of EPC includes treatment of seizures as well as underlying causes. Amongst the AEDs, levetiracetam, and topiramate are found to be more effective in EPC (1). Corticosteroid has been used in patients with EPC due to Rasmussen encephalitis and Hashimoto encephalitis. In a patient with Hashimoto encephalitis, there was complete remission of EPC on day 37 of IV methylprednisolone (1 g/day) followed by prednisolone (60 mg/day) treatment (2).

In a retrospective analysis of 11 patients with Rasmussen encephalitis, corticosteroid was not effective in controlling seizure in seven patients, who needed hemispherectomy. Five patients initially improved, but two had a recurrence of seizure after 1-4 years. Two died and one had complete remission for three years (6). Hart et al. (3) reported a more than $50 \%$ reduction in seizures following corticosteroids in eight out of 17 patients with refractory epilepsy. In our cohort, EPC in the patient with tuberculoma did not respond to six AEDs, but his seizure subsided on the $5^{\text {th }}$ day of IV methylprednisolone treatment. His AEDs were reduced to two drugs at 4 months follow up, and there was no recurrence of seizure for 1 year. This patient was diagnosed as having probable tuberculous meningitis because of CSF changes (predominant lymphocytic pleocytosis and elevated protein), and the presence of meningeal enhancement and an enhancing granuloma.
Tuberculous meningitis is a common cause of chronic meningitis in developing countries. Bacteriologic confirmation of tuberculous meningitis could be obtained in less than $50 \%$ of patients (7). Moreover, our patient's CSF was negative for fungus and other bacteria. The diagnosis of neurocysticercosis in the fourth patient was based on multiple ring-enhancing lesions and the presence of scolex in some cystic lesions. On cranial MRI or CT scans, the presence of scolex inside a cystic lesion is considered as definite neurocysticercosis (8). In the child with an old anterior cerebral artery infarction and another with normal MRI, the EPC converted to occasional discrete seizure following corticosteroid treatment. The difference in seizure response may be due to the underlying etiology of EPC. Both patients with inflammatory granuloma had complete seizure remission following corticosteroid. Among the corticosteroids, hydrocortisone is short-acting and the least potent. Prednisone and methylprednisolone are intermediateacting corticosteroids, are four to five times more potent than hydrocortisone, and dexamethasone is a long-acting corticosteroid having 25 times greater potency than hydrocortisone (9). In CNS infections, there is increased oxidative stress, cytokine release, and T-cell activation (10). These mediators may be suppressed by corticosteroids and may be the reason for the total suppression of EPC in two of our patients with inflammatory granuloma. A similar response has also been reported in patients with EPC or refractory seizures due to tuberculosis, neurocysticercosis, and malignancy $(11,12)$. EPC in chronic infarction or with normal MRI may be

Table 1. Clinical, MRI and treatment details of the children with epilepsia partialis continua

\begin{tabular}{|c|c|c|c|c|}
\hline & Patient 1 & Patient 2 & Patient 3 & Patient 4 \\
\hline Age & 8 months & 9 years & 17 years & 11 years \\
\hline Sex & Female & Male & Male & Male \\
\hline Etiology & Old infarct & Tuberculosis & Unknown & NCC \\
\hline Duration of EPC & 210 days & 13 days & 15 days & 3 days \\
\hline AEDs before steroid & $\begin{array}{l}\text { CBZ ( } 50 \mathrm{mg} \text { TDS), clobazam } \\
(2.5 \mathrm{mg} \mathrm{BD}), \mathrm{VPA}(100 \mathrm{mg} \\
\text { TDS), } \\
\text { LEV (100 mg BD) }\end{array}$ & $\begin{array}{l}\text { PHT (100 mg BD), VPA } \\
\text { (300 mg BD), LEV ( } 500 \\
\text { mg BD), clobazam ( } 5 \mathrm{mg} \\
\text { BD), CBZ (200 mg BD), } \\
\text { acetazolamide ( } 125 \mathrm{mg} \\
\text { BD), topiramate }(50 \mathrm{mg} \\
\text { BD) and IV LOR ( } 4 \mathrm{mg})\end{array}$ & $\begin{array}{l}\text { CBZ ( } 400 \mathrm{mg} \text { BD), PB } \\
(90 \mathrm{mg} \text { OD), IV LOR } \\
(4 \mathrm{mg})\end{array}$ & $\begin{array}{l}\text { VPA }(300 \mathrm{mg} \text { BD }), \\
\text { clobazam ( } 5 \mathrm{mg} \mathrm{BD})\end{array}$ \\
\hline Corticosteroid & $\begin{array}{l}\text { Prednisolone } \\
7.5 \mathrm{mg} \text { for } 1 \text { month followed } \\
\text { by } 5 \mathrm{mg} \text { for } 1 \text { month and } 2.5 \\
\text { mg for another month }\end{array}$ & $\begin{array}{l}\text { Methylpred nisolone } 500 \\
\text { mg for } 5 \text { days followed by } \\
30 \mathrm{mg} \text { for one month then } \\
\text { tapered and stopped in the } \\
\text { next month }\end{array}$ & $\begin{array}{l}\text { Dexamethasone } 8 \mathrm{mg} \\
\text { TDS for a week then } \\
\text { tapered off in the next } \\
\text { weeks }\end{array}$ & $\begin{array}{l}\text { Prednisolone } 20 \\
\text { mg for } 1 \text { month } \\
\text { then tapered to } 5 \\
\text { mg every week and } \\
\text { stopped }\end{array}$ \\
\hline Follow-up & $\begin{array}{l}\text { Four discrete seizures in } 6 \\
\text { months }\end{array}$ & Seizure-free at 1 year & $\begin{array}{l}\text { Two discrete seizures at } \\
6 \text { months }\end{array}$ & $\begin{array}{l}\text { Seizure-free at } 8 \\
\text { months }\end{array}$ \\
\hline
\end{tabular}


due to neuronal arborization and change in plasticity, which may not respond well to corticosteroids and other immunomodulators.

A short course of corticosteroids may be tried in the patients with refractory EPC, especially in patients with CNS infections.

\section{Acknowledgements}

We thank Mr. Shakti Kumar for his secretarial help.

\section{Ethics}

Informed Consent: Informed consent was obtained from all the patients included in the study.

Peer-review: Externally and internally peer-reviewed.

\section{Authorship Contributions}

Concept: J.K., U.K.M., Design: J.K., U.K.M., Data Collection or Processing: P.C.P. S.K.C., V.K.S., Analysis or Interpretation: V.K.S., U.K.S., Literature Search: J.K., V.K.S., U.K.M., Writing: J.K., U.K.M.

Conflict of Interest: No conflict of interest was declared by the authors.

Financial Disclosure: The authors declared that this study received no financial support

\section{References}

1. Mameniskiene R, Bast T, Bentes $\mathrm{C}$, et al. Clinical course and variability of non-Rasmussen, nonstroke motor and sensory epilepsia partialis continua: a European survey and analysis of 65 cases. Epilepsia 2011;52:1168-1176.
2. Masuda H, Mori M, Ito S, Yagishita T, Kuwabara S. Steroid-responsive epilepsia partialis continua with anti-thyroid antibodies: a spectrum of hashimoto's encephalopathy? Case Rep Neurol 2014;6:166-170.

3. Hart YM, Cortez M, Andermann F, et al. Medical treatment of Rasmussen's syndrome (chronic encephalitis and epilepsy): effect of high-dose steroids or immunoglobulins in 19 patients. Neurology 1994;44:1030-1036.

4. Fejerman N, Di Blasi AM. Status epilepticus of benign partial epilepsies in children: report of two cases. Epilepsia 1987;28:351-355.

5. Mbizvo GK, Lentel IC, Leen C, et al. Epilepsia partialis continua complicated by disseminated tuberculosis and hemophagocytic lymphohistiocytosis: a case report. J Med Case Rep 2019;13:191.

6. Bahi-Buisson N, Villanueva V, Bulteau C, et al. Long term response to steroid therapy in Rasmussen encephalitis. Seizure 2007;16:485-492.

7. Zoorob RJ, Cender D. A different look at corticosteroids. Am Fam Physician 1998;58:443-450.

8. Del Brutto OH, Nash TE, White AC Jr, et al. Revised diagnostic criteria for neurocysticercosis. J Neurol Sci 2017;372:202-210.

9. Misra UK, Kalita J, Tripathi A, Kumar M. Oxidative and endoplasmic reticulum stress in tuberculous meningitis related seizures. Epilepsy Res 2019;156:106160.

10. Wilkinson RJ, Rohlwink U, Misra UK, et al. Tuberculous meningitis international research consortium. tubercuslous meningitis. Nat Rev Neurol 2017;13:581-598.

11. Asranna A, Sureshbabu S, Mittal G, et al. Abdominal epilepsia partialis continua in neurocysticercosis. Epileptic Disord 2019;21:302-306.

12. Ramos AB, Cruz RA, Villemarette-Pittman NR, Olejniczak PW, Mader EC Jr. Dexamethasone as abortive treatment for refractory seizures or status epilepticus in the inpatient setting. J Investig Med High Impact Case Rep 2019;7:2324709619848816. 